\title{
RAZLIKE U PERCEPCIJI ŠKOLSKE KLIME SREDNJOŠKOLACA S OBZIROM NA OSNIVAČA ŠKOLE
}

\author{
Izv. prof. dr. sc. Nena Rončević \\ Sveučilište u Rijeci, Filozofski fakultet u Rijeci, Odsjek za pedagogiju \\ Rijeka, Hrvatska \\ Jelena Beno \\ Rijeka, Hrvatska \\ Nena Vukelić, mag. psi. \\ Sveučilište u Rijeci, Filozofski fakultet u Rijeci, Odsjek za pedagogiju \\ Rijeka, Hrvatska
}

\begin{abstract}
Sažetak:
Školska klima podrazumijeva relativno trajnu kvalitetu školske okoline nastalu kombinacijom fizičkih i socijalnih čimbenika (poput formalne organizacije, neformalne organizacije, ličnosti sudionika i specifičnosti upravljanja školom, Domović, 2003), a utječe na ponašanje njenih članova. Temelji se na zajedničkoj percepciji ponašanja svih aktera u školi. U ovom radu autorice se bave nekim aspektima percepcije školske klime srednjoškolaca. Istraživanje je provedeno na uzorku od 287 srednjoškolaca iz šest srednjih škola na području Zagreba, Rijeke i Osijeka. Dva su temeljna cilja ovoga rada. Prvi cilj istraživanja bio je ispitati metrijske karakteristike instrumenta Hrvatskog upitnika školske klime za učenike (HUŠK-U, Velki i Kuterovac Jagodić, 2012) na srednjoškolskom uzorku. Potvrđena je jednofaktorska struktura i visoka pouzdanost upitnika za srednjoškolsku populaciju. Drugi cilj rada bio je utvrditi postoji li razlika u percepciji školske klime između državnih škola i škola čiji je osnivač vjerska zajednica s pravom javnosti. Rezultati upućuju na općenito pozitivnu percepciju školske klime na uzorku srednjoškolaca. lako su na razini lokacije škola obuhvaćenih ovim istraživanjem pronađeni specifični obrasci percepcije školske klime učenika iz državnih škola i škola čiji je osnivač vjerska zajednica s pravom javnosti, na ukupnom uzorku nije pronađena razlika u percepciji školske klime između tih dviju skupina učenika. Pronađena je samo razlika u percepciji školske klime između mlađih i starijih srednjoškolaca. Sukladno s prijašnjim istraživanjima mlađi srednjoškolci percipiraju školsku klimu pozitivnijom od starijih srednjoškolaca.
\end{abstract}

Ključne riječi: odnos učenik - nastavnik, srednje škole, suvremena škola, školska klima

\section{UvoD}

Škola je okruženje koje uz obitelj zauzima središnje mjesto u životu učenika. Odgojnoobrazovni nazivnik koji škola nosi ima jednu od ključnih uloga u formiranju djetetove ličnosti, a poslije odrasle osobe, stoga se može reći kako djetetovi doživljaji škole, njegove misli i osjećaji koje se veže uz nju, te doživljaji sebe u takvom okruženju stavljaju je u središte važnosti (Vasta, Haith i Miller, 1997). Škola ima veliku važnost u formiranju društvene stvarnosti i promjena, kao što i društvene promjene neprestano utječu na redefiniranje i mijenjanje pogleda na školu. U tom kontekstu razvijene su mnoge teorije i koncepti koji su školu sagledavali iz različitih perspektiva. Ipak i dalje stoji nepromijenjena činjenica kako je škola jedna od najstarijih institucija 
civilizacijskog, vjerskog i kulturnog razvoja socijalnih zajednica i pojedinaca. Funkcioniranje škole i njezinih čimbenika stoga ima direktan utjecaj na pojedinca i njegov život.

Bitna je komponenta školskog života školska klima. Sam pojam školske klime u znanstvenom diskursu pojavio se kasnih pedesetih i početkom šezdesetih godina prošloga stoljeća kao dio zanimanja za organizacijsku klimu (Baranović, Domović i Štribić, 2006). Uvidjevši da je ona jedan od važnijih segmenata funkcioniranja škole, raste broj istraživanja školske klime što rezultira činjenicom da se školska klima danas tumači i upotrebljava na različite načine. Tako neki školsku klimu nazivaju i školska atmosfera, školski svijet, školski život, školski etos, školska kultura, školski duh (Kantorova, 2009). Za školsku klimu kažu da je: „slučaj prevladavajućih uvjeta u kojima se odvija aktivnost učenja i poučavanja“ (Grgin, 1997; 202), dok Vrgoč (1997) pak na školsku klimu gleda kao širok spektar odnosa u vodstvu škole. Ti se odnosi ogledaju između nastavnika, učenika i svih zaposlenih u školi. Dodatno, poticajna školska klima vidljiva je u kvalitetnom odnosu naspram škole, odnosu među osobljem, poticanju stručnog razvitka učitelja, profesionalnog interesa, slobode pri odlučivanju i kreativnosti učitelja (Zabukovec, 1997).

lako proučavajući literaturu možemo naići na brojne definicije školske klime, sve su one suglasne u tome da je školska klima zasnovana na iskustvu multidimenzionalna, relativno trajna percepcija školskog okruženja zajedničkih članova određene škole (Domović, 2003). Pritom percepcija ovisi o tome kako pojedinac doživljava okruženje u školi: poticajnim za individualni razvoj i uključivanje pojedinca u aktivnosti škole ili destimulirajući kontekst koji pridonosi razvoju pasivnosti, agresivnosti ili pak pružanju otpora (Puzić, Baranović i Doolan, 2011). Drugim riječima, može se zaključiti kako je školska klima dio školske okoline. Ona je na taj način povezana s individualnim i afektivnim dimenzijama i sustavom vjerovanja o školi, a oni utječu na djetetov kognitivni, socijalni i emocionalni razvoj (Haynes, Emmons i Comer, 1993; Moos, 1978; Norton, 1984. prema Velki, Jagodić i Antunović, 2014). Dakle za školsku klimu možemo reći da se zasniva na obrascima iskustava aktera školskog života i reflektira norme, ciljeve, vrijednosti, interpersonalne veze, odrednice učenja i poučavanja te organizacijske strukture škole (Cohen, McCabe, Michelli i Pickeral, 2009; Domović, 2003).

Thapa, Cohen, Guffey i Higgins-D'Alessandro (2013) na temelju provedene metaanalize na 206 radova koji se bave tematikom školske klime definirali su pet dimenzija konstrukta školske klime koji su se ponavljaju kroz istraživanja i teorijska razmatranja analiziranih radova. To su: a) sigurnost, koja uključuje aspekte poput normi i pravila, fizičke sigurnosti, socijalnoemocionalne sigurnosti, b) odnosi, što uključuje poštivanje raznolikosti, školsku povezanost/ uključenost, socijalnu podršku, vođenje, c) učenje i poučavanje, koje se odnosi na socijalno, emocionalno, etičko i građansko učenje i obrazovanje, potporu u učenju, d) institucionalnu okolinu, koja se odnosi na fizičko okruženje, resurse, materijale i e) procese unaprjeđenja škole. Pritom treba uzeti u obzir da su određene dimenzije bitnije i manje bitne iz perspektive različitih davatelja procjena školske klime pa se tako instrumenti usmjereni učeničkoj procjeni u većoj mjeri baziraju na aspektima školske klime poput sigurnosti, odnosa ili odrednica učenja i poučavanja, dok su u fokusu nastavničkih procjena školske klime zastupljena i razmatranja o institucionalnoj okolini i procesima unaprjeđenja škole.

Važnost proučavanja ove tematike pronalazimo u nizu istraživanja koja su utvrdila postojanje povezanosti između školske klime i specifičnih školskih i zdravstvenih učinaka. Primjerice, pozitivna školska klima utječe na emocionalne i ponašajne ishode mladih te na mentalno i psihičko zdravlje učenika (Cohen i sur., 2009). Pozitivna školska klima smatra se sastavnim čimbenikom prevencije vršnjačkog nasilja, ali i prevencije ovisnosti i rizičnih ponašanja. Istraživanja redovito potvrđuju da je pozitivna percepcija školske klime prediktor općenite dobrobiti mladih adolescenata (Thapa i sur., 2013). Kad razmatramo čimbenike utjecaja na učeničku i nastavničku percepciju školske klime, moramo uzeti u obzir niz različitih izvora utjecaja. Pa tako Koth, Bradshaw i Leaf (2008) pronalaze da su najvažniji čimbenici utjecaja na učeničku percepciju školske klime veličina škole kao čimbenik na razini škole, a karakteristike nastavnika, veličina razreda i postotak učenika s problemima u ponašanju kao čimbenici na razini razreda. Mareš 
(2000) prema Kantorova (2009) govori o nizu varijabli koje se mogu istraživati kao karakteristike koje utječu na školsku klimu. Neke su od njih opremljenost škole, stil vođenja, društveno stanje izvan škole, nastavnička posvećenost školi i školskom poslu te specifičnosti učenika.

\section{Problem ISTRAŽıVANJA}

Istraživanja školske klime u Hrvatskoj iz perspektive učenika malobrojna su, o čemu govori činjenica da su i instrumenti namijenjeni mjerenju tog specifičnog konstrukta relativno novi. U ovom istraživanju koristili smo se novim mjernim instrumentom Hrvatski upitnik školske klime za učenike (HUŠK-U) autorica Velki i Kuterovac Jagodić (2012). Vodeći se Perkinsonovom (2007) definicijom školske klime, koja definira školsku klimu kao okružje za učenje koje se stvara kroz interakcije i povezanost ljudi, fizičke okoline i psihološke atmosfere, cilj je autorica ovog upitnika bio da adaptiraju upitnik školske klime koji će ispitivati opći faktor školske klime mjeren učeničkom samoprocjenom te koji će biti prilagođen našoj kulturi i našem obrazovnom sustavu (Velki, Kuterovac Jagodić i Antunović, 2014). Polazeći od ideje da nije opravdano koristiti se američkim i općenito inozemnim mjernim instrumentima na hrvatskoj populaciji, konstruirale su mjerni instrument koji bi trebao biti odraz specifičnog kulturološkog okruženja i obrazovnog sustava. Autorice su instrument namijenile učenicima viših razreda osnovne škole, no i same predlažu validaciju upitnika na srednjoškolskom uzorku. Zanimljivo je, također, napomenuti da su dosad sudionici istraživanja školske klime iz učeničke perspektive u Hrvatskoj uglavnom bili učenici osnovnih škola (Puzić, Baranović i Doolan, 2011; Relja, 2006; Vlah i Perger, 2015), a rijetka su istraživanja koja uključuju učenike srednjih škola (Bouillet i Bijedić, 2007). Upravo s ciljem proširenja spoznaja o školskoj klimi i validacije mjernog instrumenta na specifičnoj populaciji, u ovom smo istraživanju koristili HUŠK-U na uzorku hrvatskih srednjoškolaca (gimnazijalaca).

Srednju školu kao odgojno-obrazovnu ustanovu mogu osnovati ${ }^{1}$ : Republika Hrvatska, jedinica područne (regionalne) samouprave i druga pravna ili fizička osoba. Osnivač škole pritom je dužan prije osnivanja školske ustanove, pribaviti prethodno pozitivno mišljenje Ministarstva o opravdanosti osnivanja školske ustanove, uzimajući u obzir programsku opravdanost, zahtjeve dostupnosti, racionalnosti i drugih relevantnih pokazatelja opravdanosti osnivanja školske ustanove. Škola kojoj je osnivač druga pravna osoba ili fizička osoba stječe naziv pravo javnosti (Narodne novine, br. 87/08, 86/09, 92/10, 105/10, 90/11, 5/12, 16/12, 86/12, 126/12, 94/13, 152/14).

Državne škole su sve one škole čiji je osnivač Republika Hrvatska ili jedinice lokalne i područne samouprave. Državne škole u koje pripadaju srednje škole koje su u interesu ovog istraživačkog rada svoje djelovanje organiziraju sukladno Zakonu o odgoju i obrazovanju, Godišnjem programu rada i orijentacijskom kalendaru rada ustanove te Kurikulumu kojim su definirane sve ostale aktivnosti u školi. Državne škole učenicima omogućavaju uz redovitu nastavu, pohađanje izborne i fakultativne nastave, dopunske i dodatne nastave, izvannastavne i izvanškolske aktivnosti. One svoje specifičnosti temelje na principu samostalnog osmišljavanja školskih kurikuluma s obzirom na specifičnosti konteksta u kojemu djeluje svaka škola. Kurikulum državnih škola temelji se na odrednicama Nacionalnog okvirnog kurikuluma, pritom vrijednosti na koje se stavlja naglasak, a trebale bi se posebno isticati u državnim školama jesu: znanje, solidarnost, identitet i odgovornost.

\footnotetext{
1 U Hrvatskoj je u školskoj godini 2014./2015. odgojno-obrazovnu djelatnost obavljalo 2130 osnovnih škola i 743 srednje škole (Državni zavod za statistiku, 2015). 743 srednje škole (državne škole) koje obavljaju odgojno-obrazovnu djelatnost u školskom sustavu RH sagledavamo u širem kontekstu jer se razlikuju tri vrste srednjoškolskih programa, a to su: gimnazije, strukovne škole i umjetničke škole.
} 
Sveobuhvatna empirijska istraživanja o karakteristikama škola čiji je osnivač katolička zajednica s pravom javnosti ne mogu se pronaći na našem području, no ipak postoje određeni radovi koje govore o karakteristikama škola čiji je osnivač katolička zajednica s pravom javnosti na području Republike Hrvatske. Prema Paloš (2010) katolička škola nastoji u svom djelovanju ostvariti sintezu između vjere i kulture, vjere i života te promicati vjersku poduku kao temeljnu sastavnicu odgojno-obrazovnog djelovanja. Školskim kurikulumom nastoji se: ostvariti da škola bude mjesto susreta odgojne kršćanske zajednice, promovirati pravedan društveni poredak, pomoći učenicima da razvijaju osobnost na temelju osobe Isusa Krista, biti u službi društvu te promicati odgojni stil škole kao zajednice uz uključivanje, vrednovanje i zalaganje odgojnoobrazovnog osoblja, učenika i njihovih roditelja (Paloš, 2010). Specifičnost odgojnog plana škola čiji je osnivač vjerska zajednica s pravom javnosti prema Hoblaj, Lončarić- Jelačić i Razum (2005) temelji se na fakultativnom dijelu kurikuluma. Katolička škola dužna je, kao i javna škola, ostvarivati obavezni (zajednički) i izborni dio nastavnog plana i programa, dok je fakultativni dio prepušten njezinoj kompetenciji ${ }^{2}$. Specifičnost katoličke škole ogleda se u činjenici i da odgojno-obrazovno osoblje promiče i podupire ciljeve i etos katoličke škole. Učitelj u katoličkoj školi tako je pozvan biti: stručnjak u podučavanju i odgoju, kršćanski odgojitelj, te osoba koja pomaže učenicima na putu njihovoga ljudskog i duhovnog rasta i sazrijevanja (Paloš, 2010) ${ }^{3}$.

Stoga je drugi cilj ovoga rada bio ispitati postoje li razlike u percepciji školske klime učenika s obzirom na različite osnivače: državnih gimnazija čiji je osnivač Republika Hrvatska ili jedinice lokalne i područne samouprave i gimnazija čiji je osnivač katolička zajednica s pravom javnosti. U ovom kontekstu usmjereni smo na katoličke gimnazije jer postoji mali broj srednjih škola čiji je osnivač druga vjerska zajednica s pravom javnosti (osim katoličkih) koje prate program drugačiji od gimnazijskog te ne bi bilo moguće provoditi usporedbu državnih i vjerskih strukovnih i/ili umjetničkih škola.

\section{Metoda}

\section{Ciljevi istraživanja i hipoteza}

Prvi cilj bio je utvrditi metrijske karakteristike instrumenta Hrvatskog upitnika školske klime (HUŠK-U, Velki i Kuterovac Jagodić, 2012) na srednjoškolskom uzorku te dodatno utvrditi postoje li razlike u percepciji školske klime gimnazijalaca s obzirom na osnivača škole koju pohađaju (državne i katoličke škole), razred i lokaciju škole (Zagreb, Rijeka i Osijek).

U istraživanju je postavljena hipoteza:

$H_{1}$ : Postoji razlika u školskoj klimi s obzirom na osnivača škole koju ispitanici pohađaju, razred koji pohađaju i lokaciju škole koju pohađaju.

\section{Uzorak ispitanika}

U istraživanju je sudjelovalo 287 ispitanika, od toga 36,2\% (104) mladića i 63,8\% (183) djevojaka. Ispitanici su bili učenici prvih i četvrtih razreda gimnazija s područja Rijeke, Zagreba

2 Kroz njega u duhu evanđelja dolazi do izražaja ono što daje posebnost odnosno identitet pojedine škole. Odgojni plan kojim se izgrađuje odgojni ambijent povećava kvalitetu odgojnog procesa, pritom djeca i učenici imaju moguć nost da budu aktivni, međuljudski odnosi u školskoj zajednici su zadovoljavajući; teži se za boljom kvalitetom u aktivnoj suradnji s obiteljima, itd.

3 „Katolička škola je više od obrazovne institucije. Za mnoge je velika obitelj. To je mjesto kamo pripadaju, mjesto gdje se stječu doživotne veze, mjesto koje daje sigurnost i zaštitu od društvenih prijetnji droge i kriminala, konačno to je mjesto koje ih povezuje sa širom zajednicom, njihovim vjerskim porijeklom i identitetom" (Angelico, 1997., prema Tunjić, 2012; 47). Karakter katoličke škole očituje se u vjerskim istinama i načelima. Postoji stav kako su katoličke škole visoko cijenjene jer omogućavaju autentično vjersko obrazovanje, stabilan sustav u kojemu se osigurava okolina koja je sigurna i u kojoj se promiču kršćanske vrijednosti kao i čvrsta disciplina (Tunjić, 2012). 
i Osijeka. U istraživanju su sudjelovale tri državne gimnazije i tri katoličke gimazije s pravom javnosti. Riječ je o namjernom i prigodnom uzorku koji je odabran na temelju spremnosti na suradnju ravnatelja i stručnih službi u školama, a ne nekog drugog sistematskog faktora.

\section{Instrument istraživanja}

Instrument kojim se mjerila školska klima sastojao se od čestica koje se odnose na instrument Hrvatski upitnik školske klime (HUŠK-U; Velki i Kuterovac Jagodić, 2012). Instrument je namijenjen mjerenju opće kvalitete školskog okruženja i psihološke atmosfere u školi, a primarno je namijenjen učenicima viših razreda osnovne škole. Upitnik se sastoji od 15 tvrdnji koje se odnose na aspekte osjećaja sigurnosti i pripadnosti školi (npr. Osjećam da pripadam školi koju pohađam), odnose nastavnika i učenika (npr. Učenici u mojoj školi imaju povjerenja u nastavnike), atmosferu za učenje (npr. Moja škola je ugodno mjesto) te roditeljsku povezanost sa školom i uključenost u školski život djece (npr. Moji roditelji/skrbnici ponosni su na mene). Zadatak učenika jest da izraze stupanj slaganja sa svakom od navedenih tvrdnji na skali Likertovog tipa od 5 stupnjeva (1- uopće se ne slažem, 5-potpuno se slažem). U originalnoj verziji upitnika koristi se obrnuta skala (1-potpuno se slažem, 5-uopće se ne slažem), no zbog usklađivanja skale procjene s ostalim upitnicima korištenima u većem istraživanju, obrnuta je skala procjene. Rezultat se formira zbrajanjem procjena za sve čestice i kreće se u teoretskom rasponu od 15 do 75, što je slučaj i u našem istraživanju. Viši rezultat upućuje na percepciju pozitivnije školske klime. Unutarnja je konzistencija ovog upitnika visoka i iznosi $\alpha=0,88-0,92$ (Velki, Kuterovac Jagodić i Antunović, 2014). U našem istraživanju pouzdanost upitnika iznosi $\alpha=0,89$.

\section{Provjera faktorske strukture Hrvatskog upitnika školske klime na uzorku hrvatskih gimnazijalaca}

Kako bi provjerili potvrđuju li naši podatci faktorsku strukturu originalnog instrumenta HUŠK-U na uzorku hrvatskih gimnazijalaca iz srednjih škola Rijeke, Osijeka i Zagreba (N=287) provedena je eksploratorna faktorska analiza metodom glavnih komponenti. Kako bi se započelo s procjenom faktorske valjanosti skale koja se sastoji od 15 čestica provjerena je značajnost KMO testa i Bartlettovog testa sfericiteta. KMO test nije značajan ( $p>0,05)$, dok je Bartlettov test statistički značajan $\left(\chi^{2}=1729,83 ; \mathrm{df}=105, \mathrm{~N}=286, \mathrm{p}<0,01\right)$, što navodi na opravdanost računanja faktorske strukture upitnika.

Prema Guttman-Kaiserovom kriteriju utvrđena su dva faktora koja objašnjavaju 51,41\% varijance, dok se prema kriteriju Scree testa jasno izdvojio jedan faktor koji objašnjava 41,83\% varijance. Nijedna čestica nije imala nisko faktorsko zasićenje $(<0,3)$. Na uzorku srednjoškolaca, potvrđena je jednodimenzionalna struktura upitnika koju su odredile autorice instrumenta (Velki, Kuterovac Jagodić i Antunović, 2014). U Tablici 1. prikazana je matrica komponenata čestica upitnika za jednofaktorsku strukturu, kao i koeficijent pouzdanosti. 
Tablica 1. Matrica komponenata čestica HUŠK-U upitnika za jednofaktorsku soluciju i koeficijent pouzdanosti

\begin{tabular}{|c|c|c|}
\hline \multicolumn{2}{|c|}{ Čestica } & \multirow{2}{*}{$\begin{array}{c}\begin{array}{c}\text { Faktorsko } \\
\text { zasićenje }\end{array} \\
0,630\end{array}$} \\
\hline 1. & Učenici u mojoj školi imaju povjerenja u nastavnike. & \\
\hline 2. & Nastavnici u mojoj školi mogu zaustaviti zadirkivanje i nasilje među učenicima. & 0,629 \\
\hline 3. & U mojoj školi nastavnici poštuju učenike. & 0,740 \\
\hline 4. & U mojoj školi nastavnici su ravnopravni i fer prema svim učenicima. & 0,693 \\
\hline 5. & Nastavnici mi pomažu da imam dobro mišljenje o sebi. & 0,717 \\
\hline 6. & Mojim nastavnicima je stalo da budem uspješan u školi. & 0,631 \\
\hline 7. & U školi se osjećam sigurno. & 0,681 \\
\hline 8. & Uživam učiti u svojoj školi. & 0,680 \\
\hline 9. & Većinom se radujem odlasku u školu. & 0,492 \\
\hline 10. & U mojoj školi školska pravila su pravedna. & 0,685 \\
\hline 11. & Moja škola je ugodno mjesto. & 0,780 \\
\hline 12. & Osjećam da pripadam školi koju pohađam. & 0,679 \\
\hline 13. & U mojoj školi uvijek imam priliku obratiti se nekome za pomoć ako mi je ona potrebna. & 0,673 \\
\hline 14. & Moji roditelji su ponosni na mene. & 0,369 \\
\hline \multirow[t]{4}{*}{15.} & Ako budem marljivo učio u školi, postat ću uspješna odrasla osoba. & 0,494 \\
\hline & Svojstvena vrijednost & 6,274 \\
\hline & Objašnjena varijanca & $41,83 \%$ \\
\hline & Cronbach $\alpha$ & 0,89 \\
\hline
\end{tabular}

\section{Postupak prikupljanja podataka}

Istraživanje je provedeno 2016. godine krajem mjeseca travnja i početkom mjeseca svibnja na način da se cjelokupno mjerenje provodilo u učionici nakon predmetne nastave. U Zagrebu i Osijeku istraživanje je provedeno u dogovoru i suradnji s djelatnicima škole, dok su u Rijeci istraživači izravno proveli istraživanje u školama. Za prikupljanje podataka koristio se postupak anketiranja. Prije samog početka ispitivanja ispitanicima se objasnila svrha provođenja ispitivanja te naglasila anonimnost danih podataka. Popunjavanje upitnika trajalo je oko 15 minuta.

\section{Obrada podataka}

Podaci su obrađeni Statističkim programom za društvene znanosti (IBM SPSS, 23.0.). U obradi podataka koristile su se metode univarijatne statistike (postoci, mjere centralne tendencije i mjere varijabilnosti) i metode multivarijatne statistike (eksploratorna faktorska analiza i trosmjerna analiza varijance) za utvrđivanje razlika s obzirom na definirane nezavisne varijable i testiranje valjanosti instrumenta.

\section{REZULTATI I RASPRAVA}

$\mathrm{U}$ istraživanju je sudjelovalo $51,6 \%$ ispitanika iz državnih gimnazija i $48,4 \%$ ispitanika iz škola čiji je osnivač katolička zajednica s pravom javnosti. Podjednak se broj ispitanika iz prvih $(52,6 \%)$ i četvrtih razreda $(47,4 \%)$ ovih škola uključio u istraživanje. 


\section{Deskriptivni pokazatelji}

Tablica 2. Deskriptivna statistika HUŠK-U upitnika i rezultati testiranja normalnosti distribucije na uzorku hrvatskih srednjoškolaca

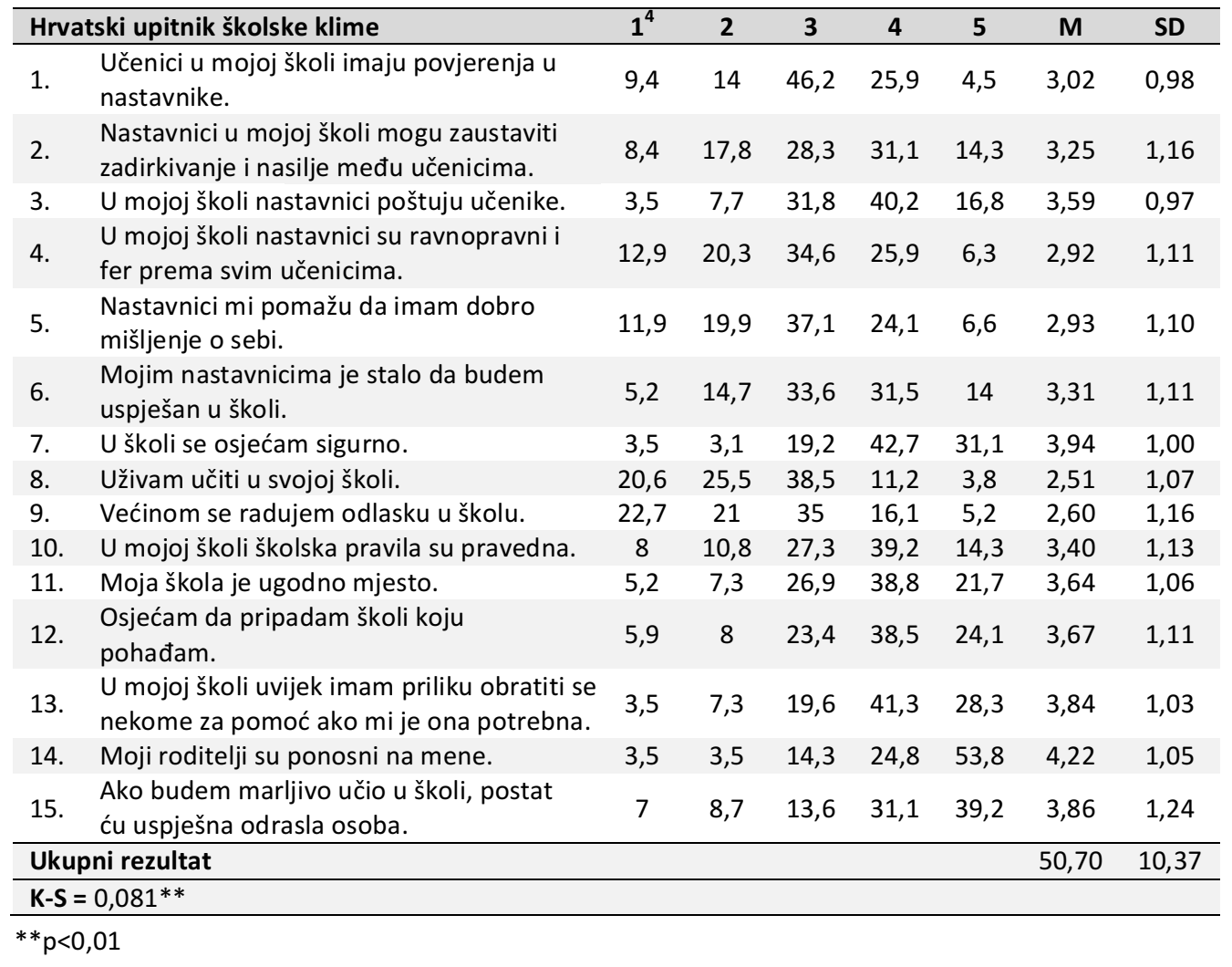

Prikazani su postoci odgovora ispitanika, aritmetičke sredine i standarde devijacije za svaku česticu iz Hrvatskog upitnika školske klime te je provjerena normalnost distribucije rezultata (Tablica 2.). Testiranjem normalnosti distribucije rezultata Kolmogorov-Smirnov testom utvrđeno je da distribucija statistički rezultata značajno odstupa od normalne (Tablica 2.) i negativno je asimetrična. Drugim riječima, rezultati imaju tendenciju grupiranja prema višim vrijednostima što upućuje na procjenu pozitivnije, odnosno povoljnije školske klime. To je u skladu s rezultatima Velki, Kuterovac Jagodić i Antunović (2014) prikupljenima na uzorku hrvatskih osnovnoškolaca, ali i američkim istraživanjima (Perkins, 2007) koja pokazuju da učenici rijetko percipiraju školsku klimu kao negativnu.

Hrvatski srednjoškolci pokazuju najveće slaganje s tvrdnjama Moji roditelji su ponosni na mene $(\mathrm{M}=4,22 ; \mathrm{SD}=1,05)$ i $U$ školi se osjećam sigurno $(\mathrm{M}=3,94 ; \mathrm{SD}=1)$. Većina ispitanika odgovorila je da se slažu $(24,8 \%)$ ili u potpunosti slažu $(53,8 \%)$ s tvrdnjom da su njihovi roditelji ponosni na njih. Osjećaj sigurnosti u školi je vrlo visoko procijenjen, pa tako većina ispitanika procjenjuje da se u školi osjećaju vrlo sigurnima (73,8\%). Osjećaj sigurnosti potvrđuje se i s visokom procjenom ispitanika kako se u svojoj školi uvijek imaju priliku obratiti nekome za pomoć ako im je ona potrebna $(69,6 \%)$. Osjećaj sigurnosti jedan je od najsnažnijih prediktora po-

4 Na ljestvici od 1 do 5 (1 - uopće se ne slažem do 5 - u potpunosti se slažem), $M=$ aritmetička sredina, SD= standardna devijacija 
zitivne školske klime (Samdal, Nutbeam, Wold i Kannas, 1998; Thapa i sur., 2013). S druge strane negativna školska klima povezana je s češćim doživljavanjem vršnjačkog nasilja i viktimizacijom (Kartal i Bilgin, 2009; Puzić, Baranović i Doolan, 2011; Velki, Kuterovac Jagodić i Antunović, 2014; Velki i Vrdoljak, 2013; Vlah i Perger, 2015), a posljedično i s nizom negativnih obrazovnih ishoda poput odustajanja od škole (Palardy, 2008; Ozmusul, 2016). Učenici koji procjenjuju niski stupanj sigurnosti u školskom okruženju, redovito procjenjuju i školsku klimu negativnijom.

O karakteristikama školskog ozračja i školske klime također govore i podaci o tome kako su percipirani odnosi učenika i njihovih nastavnika. Odnos nastavnik - učenik procijenjen je vrlo pozitivno samo na čestici $U$ mojoj školi nastavnici poštuju učenike, dok je u ostalim varijablama (poput procjene pravednosti nastavnika, povjerenja u nastavnike, sposobnosti nastavnika da riješe međuvršnjačke sukobe, itd.) postojala velika diferencijacija u odgovorima. Na sličan su rezultat naišli i Puzić, Baranović i Doolan (2011), proučavajući aspekte školske klime učenika osmih razreda osnovnih škola u Zagrebu. Autori su pronašli da iako većina ispitanika percipira nastavnike kao osobe od kojih mogu dobiti podršku pri rješavanju sukoba s drugim učenicima, mali postotak njih se složio $s$ tvrdnjom da se nastavnici ponašaju pravedno prema učenicima, a određeni postotak ispitanika (njih oko $16 \%$ ) u potpunosti se složilo s tvrdnjom da nastavnici ismijavaju ili vrijeđaju učenike. Relja (2006) je u svom istraživanju pokazala kako učenici starije školske dobi uočavaju problem u komunikaciji na relaciji odrasla osoba - mlada osoba, učenik - nastavnik. Mlada osoba tako želi bolju komunikaciju i više razgovora, druženja, razumijevanja za probleme odrastanja koje u većini slučajeva ne nalaze kod odraslih pa tako ni kod svojih nastavnika. Lee i Smith (2001) prema Roviš i Bezinović (2011) smatraju kako se u srednjim školama sve učestalije zbog njihove veličine kao i "birokratiziranosti" nastave narušava osjećaj zajedništva između nastavnika i učenika. Učenici tako više nemaju toliko prilika bolje upoznati svoje nastavnike i tako stvoriti pozitivan odnos s važnijom odraslom osobom izvan obiteljskog okruženja. Rezultat toga pokazuje se u međusobnom nepovjerenju i udaljavanju od zajedničkih vrijednosti i ciljeva školskog obrazovanja, čime se direktno smanjuje uključenost u obrazovni proces i motivacija učenika (Roviš i Bezinović, 2011). Te rezultate potvrdilo je i ovo istraživanje koje je pokazalo kako učenici nemaju povjerenja u nastavnike, te ne mogu procijeniti imaju li nastavnici ravnopravan odnos prema učenicima i jesu li pravedni.

Kao vrlo zanimljivi rezultati ovog istraživanja pokazale su se procjene (ne)slaganja $s$ tvrdnjama Uživam učiti u svojoj školi $(\mathrm{M}=2,51 ; \mathrm{SD}=1,07)$ i Većinom se radujem odlasku u školu $(M=2,60 ; S D=1,16)$. Ispitanici pokazuju najmanje slaganje upravo s tim česticama iz Hrvatskog upitnika školske klime. Nešto malo manje od polovice ispitanika $(46,1 \%)$ ne slaže se ili u potpunosti ne slaže s tvrdnjom da uživaju učiti u školi, dok njih samo $15,1 \%$ uživa učiti u svojoj školi. Također se nešto malo manje od polovice ispitanika $(43,7 \%)$ većinom ne raduje odlasku u školu, dok njih samo $21,3 \%$ radosno odlazi u školu. Iz ovog rezultata proizlazi potreba za redefiniranjem učenja kao „mučenja“ kroz pretpostavku da će učenici biti usmjereniji prema učenju i radu ako su učenicima sadržaji koje uče u školi i metode poučavanja koje se primjenjuju zanimljive, ako ih smatraju važnima za život i budućnost i ako su učionice mjesta gdje se osjećaju prihvaćenima (Raboteg- Šarić, Šakić i Brajša- Žganec, 2009). Vrlo je zanimljivo kako učenici bez obzira na to što su procijenili kako ne uživaju učiti u svojoj školi, smatraju kako je marljivo učenje u školi put kojim se ide kako bi se postala uspješna odrasla osoba. „Ako budem marljivo učio u školi, postat ću uspješna odrasla osoba" procijenilo je sa slaganjem 70,5\% ispitanika. Odnos prema školi može imati „izravan utjecaj na obrazovne ishode poput boljeg školskog uspjeha, više motivacije za učenje, većeg samopouzdanja, češćeg sudjelovanja u izvanškolskim aktivnostima i retenciju u sustavu obrazovanja (Thompson, 2006.; Waters, Cross i Runions, 2009. prema Roviš i Bezinović, 2011;186).

Za detaljniju sliku i uvid u tematiku percepcije školske klime hrvatskih gimnazijalaca, provedena je trosmjerna analiza varijance na rezultatima prikupljenima pomoću Hrvatskog upitnika školske klime (Velki i Kuterovac Jagodić, 2012). 


\section{Razlike u procjenama školske klime s obzirom na osnivača, razred i lokaciju škole}

U svrhu odgovaranja na cilj rada i utvrđivanja razlika u percepciji školske klime gimnazijalaca, provedene su daljnje analize. Provedena je trosmjerna analiza varijance $2 \times 2 \times 3$ da bi se provjerilo postoji li razlika u procjenama školske klime s obzirom na osnivača (državna gimnazija, katolička gimnazija s pravom javnosti), razred (1. i 4. razred srednje škole) i lokaciju škole (Rijeka, Zagreb i Osijek). Rezultati su prikazani u Tablici 3.

Utvrđen je glavni efekt razreda, dok se efekti osnvača i lokacije škole nisu pokazali značajnima. Učenici prvih razreda srednje škole $(M=53,12 ; S D=8,59)$ procjenjuju školsku klimu pozitivnijom od učenika četvrtih razreda srednje škole $(M=48,5 ; S D=11,34)$. Ovi rezultati potvrđuju i rezultate prijašnjih istraživanja koja su se bavila pitanjima dobnih razlika u percepciji školske klime (Reić- Ercegovac i Koludrović, 2010; Relja, 2006; Samdal i sur., 1998; Velki, Kuterovac Jagodić i Antunović, 2014). Učenici prvih razreda srednjih škola nalaze se tek na početku srednjoškolskog obrazovanja, te je njihova usmjerenost na školu još uvijek pod utjecajem pozitivnih emocija osnovnoškolskog razdoblja, kao i razvojnog perioda u kojemu se nalaze.

Tablica 3. Prikaz deskriptivnih podataka i glavnih efekata analize varijance za školsku klimu s obzirom na osnivača, razred i lokaciju škole ( $N=287)$

\begin{tabular}{|c|c|c|c|c|c|c|c|c|c|c|c|c|}
\hline \multirow{3}{*}{$\begin{array}{l}\text { Vrsta } \\
\text { škole }\end{array}$} & \multirow{3}{*}{ Razred } & \multicolumn{8}{|c|}{ Lokacija škole } & \multicolumn{3}{|c|}{ ANOVA (F) } \\
\hline & & \multicolumn{2}{|c|}{ Zagreb } & \multicolumn{2}{|c|}{ Rijeka } & \multicolumn{2}{|c|}{ Osijek } & \multicolumn{2}{|c|}{ Ukupno } & \multirow{2}{*}{$\begin{array}{l}\text { Vrsta } \\
\text { škole } \\
F_{(1,274)} \\
\end{array}$} & \multirow{2}{*}{$\begin{array}{l}\text { Razred } \\
F_{(1,274)}\end{array}$} & \multirow{2}{*}{$\begin{array}{c}\begin{array}{c}\text { Lokacija } \\
\text { škole }\end{array} \\
F_{(2,274)}\end{array}$} \\
\hline & & $M$ & SD & $\mathrm{M}$ & SD & $M$ & SD & $\mathrm{M}$ & SD & & & \\
\hline \multirow{3}{*}{$\begin{array}{l}\text { Državna } \\
\text { gimnazija }\end{array}$} & Prvi & 56,25 & 8,6 & 52,74 & 5,52 & 51,12 & 6,77 & 53,42 & 7,41 & \multirow{9}{*}{1,12} & \multirow{9}{*}{$14,14^{* *}$} & \multirow{9}{*}{1,4} \\
\hline & Četvrti & 51,38 & 11,68 & 46,83 & 9,79 & 43,19 & 13,14 & 46,96 & 11,86 & & & \\
\hline & Ukupno & 53,81 & 10,44 & 49,12 & 8,82 & 46,92 & 11,26 & 49,89 & 10,57 & & & \\
\hline \multirow{3}{*}{$\begin{array}{l}\text { Katolička } \\
\text { gimnazija } \\
\text { s pravom } \\
\text { javnosti }\end{array}$} & Prvi & 48,91 & 11,21 & 55,26 & 8,94 & 54,3 & 7,6 & 52,83 & 9,65 & & & \\
\hline & Četvrti & 49,74 & 10,41 & 51,46 & 11,58 & 49,32 & 9,39 & 50,3 & 10,49 & & & \\
\hline & Ukupno & 49,29 & 10,73 & 53,18 & 10,55 & 51,87 & 8,79 & 51,57 & 10,13 & & & \\
\hline \multirow{3}{*}{ Ukupno } & Prvi & 52,66 & 10,53 & 54,12 & 7,61 & 52,68 & 7,29 & 53,12 & 8,59 & & & \\
\hline & Četvrti & 50,65 & 11,04 & 49,07 & 10,85 & 45,94 & 11,9 & 48,5 & 11,34 & & & \\
\hline & Ukupno & 51,70 & 10,76 & 51,19 & 9,9 & 49,24 & 10,43 & 50,7 & 10,37 & & & \\
\hline
\end{tabular}

${ }^{* *} \mathrm{p}<0,01$; sve osim jedne interakcije nisu značajne, pa prema tome nisu prikazane zbog bolje preglednosti rezultata

Nadalje je pronađena statistički značajna interakcija osnivača i lokacije škole $(F(2,274)=$ $5,8 ; p<, 01)$. Učenici državnih gimnazija u gradu Zagrebu procjenjuju pozitivnijom školsku klimu od učenika škola čiji je osnivač vjerska zajednica s pravom javnosti, dok je situacija obrnuta u gradovima Rijeci i Osijeku. U Rijeci i Osijeku učenici škola čiji je osnivač katolička zajednica s pravom javnosti procjenjuju školsku klimu pozitivnijom od učenika državnih škola. Na temelju ovog rezultata ne možemo govoriti o sistematskim razlikama u percepciji školske klime između učenika iz državnih škola i škola čiji je osnivač vjerska zajednica s pravom javnosti, jer na percepciju školske klime utječu i drugi faktori koje bi trebalo u budućim istraživanjima detaljnije obuhvatiti i analizirati.

Valja spomenuti i neka ograničenja ovoga rada. Kao jedno od glavnih ograničenja nameće se homogenost programa srednje škole koje ispitanici pohađaju. Budući da postoji mali broj srednjih škola čiji je osnivač vjerska zajednica s pravom javnosti koje prate program drugačiji od gimnazijskog, kako bismo mogli usporediti državne i katoličke škole, uzet je uzorak učenika iz jedne državne gimnazije i jedne gimnazije čiji je osnivač katolička zajednica s pravom javnosti iz svakog od tri odabrana grada. Moguće je da bismo uključivanjem učenika iz strukovnih $i$ 
umjetničkih srednjih škola kao i drugih vjerskih zajednica, dobili drugačiju sliku školske klime hrvatskih srednjoškolaca. Ako uzmemo u obzir da gimnazije upisuju i pohađaju isključivo oni učenici koji su postizali najbolji uspjeh u osnovnoj školi, a bolji školski uspjeh povezan je s pozitivnijom percepcijom školske klime (Gareau i sur., 2009; MacNeil, Prater i Busch, 2009; Tubbs i Garner, 2008; Velki, Kuterovac Jagodić i Antunović, 2014), nameće se ideja o mogućem postojanju razlika u percepciji školske klime između gimnazijalaca i učenika iz strukovnih škola. Gimnazijalci su moguće upravo oni učenici koji imaju i pozitivniji stav prema obrazovnom procesu, učenju i školi, a posljedično i percipiraju školsku klimu pozitivnijom. Postoji li razlika u percepciji školske klime između učenika iz škola s različitim programom pitanje je na koje u svakom slučaju treba dati odgovor daljnjim istraživanjima.

Također, ograničenjem ovog istraživanje možemo smatrati to što je provedeno isključivo u urbanim sredinama. No treba naglasiti da rezultati prethodnih istraživanja (Othman i Muijs, 2013; Velki, Kuterovac Jagodić i Antunović, 2014) pokazuju nekonzistentne nalaze u tom području: ponekad nalazi idu u prilog ruralnim, a ponekad urbanim školama.

\section{ZAKLUČAK}

$U$ radu je korišten recentan mjerni instrument za procjenu školske klime namijenjen učenicima Hrvatski upitnik školske klime autorica Velki i Kuterovac Jagodić (2012). lako su autorice prvenstveno namijenile instrument učenicima viših razreda osnovne škole, i same predlažu validaciju upitnika na srednjoškolskom uzorku. U skladu s time postavljen je specifičan cilj ovog istraživanja u smislu provjere metrijskih karakteristika instrumenta na uzorku gimnazijalaca. Rezultati provedenih analiza potvrđuju jednofaktorsku strukturu i visoku pouzdanost upitnika. Dobivena struktura upitnika govori o opravdanosti izražavanja ukupnog rezultata koji predstavlja mjeru opće percepcije školske klime učenika, u ovom slučaju gimnazijalaca. Zaključno, mišljenja smo da je Hrvatski upitnik školske klime instrument primjenjiv na populaciji hrvatskih srednjoškolaca.

Sukladno drugom cilju ovog istraživanja o tome postoji li razlika u učeničkoj percepciji školske klime s obzirom na osnivača škole, razred i lokaciju škole, postavljena je afirmativna hipoteza. Hipoteza je djelomično potvrđena. Naime, nisu pronađene razlike s obzirom na vrstu i lokaciju škole, no u skladu s prethodnim istraživanjima, potvrđena je razlika u percepciji školske klime između mlađih i starijih srednjoškolaca. Mlađi gimnazijalci percipiraju školsku klimu u većoj mjeri pozitivnom nego stariji gimnazijalci. No treba naglasiti da možemo zaključiti da učenici općenito pozitivno procjenjuju školsku klimu u svojim školama. Također se dobio zanimljiv rezultat da učenici državnih gimnazija u gradu Zagrebu procjenjuju pozitivnijom školsku klimu od učenika škola čiji je osnivač katolička zajednica s pravom javnosti, dok je situacija obrnuta u gradovima Rijeci i Osijeku. U Rijeci i Osijeku učenici gimnazija čiji je osnivač katolička zajednica s pravom javnosti procjenjuju školsku klimu pozitivnijom od učenika državnih gimnazija.

U daljnjim istraživanjima bilo bi zanimljivo povezati percepciju školske klime s određenim dobno specifičnim karakteristikama uzorka (poput podložnosti društvenim utjecajima, utjecaju vršnjaka, stupnjem razvijenosti socijalnih vještine, itd.) te proširiti uzorak ispitanika na učenike strukovnih škola, kao i učenike iz područja ruralne Hrvatske. Daljnja će istraživanja svakako zahtijevati validaciju upitnika na širem i heterogenijem uzorku hrvatskih srednjoškolaca. Također bi bilo zanimljivo povezati percepciju školske klime srednjoškolaca s objektivnim pokazateljima školske klime, što u ovom istraživanju nije bio slučaj. Smatramo da ova pitanja čine zanimljive potencijalne smjernice za buduća istraživanja percepcije školske klime.

Rezultati ovoga rada predstavljaju poticaj za promišljanje o budućim istraživanjima koja će se baviti razrednim ozračjem, odnosno razrednom klimom. Važno je u tom kontekstu ispitati 
učenike na koji način oni percipiraju kvalitetnog nastavnika i koje su njihove potrebe vezane uz nastavno gradivo. Nova istraživanja trebala bi biti usmjerena na srednjoškolsko strukovno obrazovanje koje je u istraživačkom pogledu vrlo zapostavljeno. S obzirom na raznolikost i širinu rezultata dobivenih ovim istraživanjem, važno ih je razmotriti i njima se koristiti kao okvirom za intervencije nastale na znanstvenim analizama i podlogom za promjene u odgojno-obrazovnom funkcioniranju.

\section{LITERATURA}

Baranović, B., Domović, V. i Štribić, M. (2006). O nekim aspektima školske klime u osnovnim školama u Hrvatskoj, Sociologija sela, 44(174(4)): 485-504.

Beno, J. (2014). Povezanost obrazovanja roditelja i obrazovnih aspiracija srednjoškolaca (NeobjavIjeni završni rad, Sveučilište u Rijeci, Filozofski fakultet). Rijeka: Filozofski fakultet.

Bouillet, D., Bijedić, M. (2007). Rizična ponašanja učenika srednjih škola i doživljaj kvalitete razrednonastavnog ozračja, Odgojne znanosti, 9: 113-132.

Cohen, J., McCabe, E.M., Michelli, N.M. i Pickeral, T. (2009). School climate: Research, policy, practi$\mathrm{ce}$, and teacher eduaction, Teacher College Record, 111(1): 180-213.

Domović, V. (2003). Školsko ozračje i učinkovitost škole. Zagreb: Naklada Slap.

Gareau, S., Monrad, D.M., DiStefano, C., May, R.J., Price, K.J., Ishikawa, T. i Mindrila, D.L. (2009). The relationship between school climate and school performance, South Carolina Educational Policy Center, 1-11.

Grgin, T. (1997). Edukacijska psihologija. Jastrebarsko: Naklada Slap.

Hoblaj, A., Lončarić-Jelačić, N., Razum, R. (2005). Crkva i odgoj u Hrvatskoj: istraživanje za europsku komparativnu studiju, Bogoslovna smotra, 75(1): 289-313.

Kantorova, J. (2009). Školska klima - teorijska načela i istraživanje s motrišta učenika, nastavnika i roditelja, Odgojne znanosti, 11(1(17)): 183-189.

Kartal, H. i Bilgin, A. (2009). Bullying and school climate from the aspects of the students and teachers, Egitim Arastirmalari-Eurasian Journal of Educational Research, 36: 209-226.

Koth, C.W., Bradshaw, C.P. i Leaf, P.J. (2008). A multilevel study of predictors of student perceptions of school climate: The effect of classroom-level factors, Journal of Educational Psychology, 100(1): 96-104.

MacNeil , A.J., Prater, D.L. i Busch, S. (2009). The effects of school culture and climate on student achievement, International Journal of Leadership in Education, 12(1): 73-84.

Othman, M. i Muijs, D. (2013). Educational quality differences in a middle income country: the urban-rural gap in Malaysian primary schools, School Effectiveness and School Improvement, 24 (1): 104-122.

Ozmusul, M. (2016). School climate as a predictor of early school leavers, Croatian Journal of Education, 18 (2): 491-517.

Palardy, G.J. (2008). Differential school effects among low, middle, and high social class composition schools: a multiple group, multilevel latent growth curve analysis, School Effectiveness and School Improvement, 19 (1): 21-49.

Paloš, R. (2010). Izazovi i mogućnosti odgoja i obrazovanja na početku 21. stoljeća: primjer katoličke škole, Kateheza, 32(2): 101-114.

Perkins, B.K. (2007). Where we teach: The CUBE survey of urban school climate. Alexandria, VA: National School Boards Association.

Puzić, S., Baranović, B., Doolan, K. (2012). Školska klima i sukobi u školi, Sociologija i prostor, 49 (3(191)): 335-358.

Raboteg- Šarić, Z., Šakić, M., Brajša- Žganec, A. (2009). Kvaliteta života u osnovnoj školi: povezanost sa školskim uspjehom, motivacijom i ponašanjem učenika, Društvena istraživanja, 18 (4-5)(102103)): 697-716 
Reić- Ercegovac, I., Koludrović, M. (2010). Akademska samoefikasnost i školski uspjeh adolescenata, Pedagogijska istraživanja, 7(1): 111-126.

Relja, J. (2006). Kako se učenici osjećaju u školi, Život i škola, 15-16 (1-2): 87-96.

Roviš, D., Bezinović, P. (2011). Vezanost za školu - analiza privrženosti školi i predanosti školskim obvezama kod srednjoškolaca, Sociologija i prostor, 49(2(190)): 185-208.

Samdal, O., Nutbeam, D., Wold, B. i Kannas, L. (1998). Achieving health and educational goals through schools - a study of the importance of the school climate and the students' satisfaction with school, Health education research: Theory and practice, 13 (3): 383-397.

Thapa, A., Cohen, J., Guffey, S. i Higgins-D'Alessandro, A. (2013). A review of school climate research, Review of Educational Research, 83: 357-385.

Tubbs, J. E. i Garner, M. (2008). The Impact of school climate on school outcomes, Journal of College Teaching \& Learning, 5(9): 17-26.

Tunjić, N. (2003). Katolička škola pred izazovima društvenih promjena. Salezijanska klasična gimnazija s pravom javnosti: Rijeka.

Tunjić, N. (2012). Katolička škola u suvremenom svijetu. Salezijanska klasična gimnazija s pravom javnosti: Rijeka.

Vasta, R., Haith, M. M., Miller, S. A. (1997). Dječja psihologija. Jastrebarsko: Naklada Slap.

Velki, T., Kuterovac- Jagodić, Antunović, A. (2014). Razvoj i validacija hrvatskog upitnika školske klime za učenike, Suvremena psihologija, 17(2): 151-165.

Velki, T. i Vrdoljak, G. (2013). Uloga nekih vršnjačkih i školskih varijabli u predviđanju vršnjačkog nasilnog ponašanja, Društvena istraživanja, 22(1): 101-120.

Vlah, N. i Perger, S. (2015). Povezanost vršnjačkog nasilja s percipiranom školskom klimom kod učenika osnovne škole, Kriminologija i socijalna integracija, 22(1): 1-25.

Vrgoč, H. (1997). Školsko i razredno-nastavno ozračje u funkciji unapređivanja odgoja i obrazovanja. U: H. Vrgoč (ur.), Školsko i razredno-nastavno ozračje: put prema kvalitetnijoj hrvatskoj školi i nastavi (str. 9-16). Zagreb : Hrvatski pedagoško-književni zbor.

Zabukovec, V. (1997). Istraživanje razrednog ozračja- slovensko iskustvo. U: H. Vrgoč (ur.), Školsko i razredno-nastavno ozračje: put prema kvalitetnijoj hrvatskoj školi i nastavi (str. 24-32). Zagreb : Hrvatski pedagoško-književni zbor.

\section{The Differences in School Climate Perception of High School Students with Regard to the Founder of the School}

Summary: School climate entails a relatively permanent quality of the school environment, which is a result of a combination of physical and social factors (formal and informal organization, participants' personality and leadership characteristics, Domović, 2003) and it affects the behaviour of its members. It is based on a common perception of behaviour of all stakeholders in a school. In this paper, the authors focus on certain aspects of Croatian secondary school pupils' perception of the school climate. The research was conducted on a sample of 287 high school pupils attending six high schools in Zagreb, Rijeka and Osijek. There were two main aims of the study. The first aim of this study was to examine the metric properties of the instrument Croatian questionnaire of the school climate for primary school pupils (Velki \& Kuterovac Jagodić, 2012) on a sample of high school pupils. The one factor structure has been confirmed with high reliability of the questionnaire for the high school pupil population. The second aim was to examine the high school pupils' perceptions of the school climate and to determine whether there is a difference in the perception of the school climate between pupils from public schools and schools founded by religious communities. The results indicate that there is an overall positive perception of the school climate. Although particular patterns regarding certain cities have emerged between pupils from public schools and schools founded by religious communities in terms of the school climate perception, there are no differences in the perception of the school climate between the overall sample of pupils from public schools and schools founded by religious communities. The only difference in perception was found between younger and older high school pupils. In line with the previous research, younger high school pupils perceive the school climate to be more positive than their older colleagues. 
Keywords: student-teacher relationship, high school, contemporary school, school climate

\section{Unterschiede in der Wahrnehmung des Schulklimas mit Bezug auf den Schulträger}

Zusammenfassung: Unter Schulklima versteht man eine relativ dauerhafte Qualität der Schulumgebung, die aus der Kombination physischer und sozialer Faktoren (wie formale Organisation, informelle Organisation, Persönlichkeit der Teilnehmer und Besonderheiten in der Schulverwaltung, Domović, 2003) besteht und das Verhalten ihrer Mitglieder beeinflusst. Grundlage bildet die gemeinsame Wahrnehmung des Verhaltens aller Akteure in der Schule. In dieser Arbeit behandeln die Autorinnen einige Aspekte der Wahrnehmung des Schulklimas unter Schülern der Oberstufe. Die Erhebung wurde auf einer Stichprobe von 287 Schülern der Oberstufe aus sechs Sekundarschulen auf dem Gebiet der Städte Zagreb, Rijeka und Osijek durchgeführt. Die Arbeit setzte sich zwei grundlegende Ziele: das erste Ziel war es, die metrischen Eigenschaften des Instruments „Kroatischer Fragebogen für Schüler zur Meinung zum Schulklima“ (HUŠK, Velki i Kuterovac Jagodić, 2012) auf einer Stichprobe in Sekundarschulen zu erfragen. Die einfaktorielle Struktur und hohe Zuverlässigkeit des Instruments wurden auch für die Population der Sekundarschulen bestätigt. Das zweite Ziel war es festzustellen, ob es einen Unterschied in der Wahrnehmung des Schulklimas zwischen staatlichen Schulen und Schulen mit öffentlichen Glaubensgemeinschaften als Träger gibt. Die Ergebnisse weisen im Allgemeinen auf eine positive Wahrnehmung des Schulklimas unter Schülern der Oberstufe. Obwohl auf Ebene des Standortes der teilnehmenden Schulen spezifische Muster in der Wahrnehmung des Schulklimas von Schülern staatlicher Schulen einerseits und Schülern aus Schulen mit öffentlichen Glaubensgemeinschaften als Träger andererseits gefunden wurden, zeigt die gesamte Stichprobe keinen Unterschied in der Wahrnehmung des Schulklimas zwischen diesen zwei Schülergruppen. Der einzig festgestellte Unterschied in der Wahrnehmung des Schulklimas bezieht sich auf jüngere und ältere Oberstufenschüler. Den bisherigen Erhebungen entsprechend nehmen die jüngeren Schüler das Schulklima als positiver wahr, als die älteren Oberstufenschüler.

Schlüsselwörter: Beziehung Schüler-Lehrer, Sekundarschulen, zeitgemäße Schule, Schulklima 